\title{
Mediating Role of Organizational Culture in The Relationship between Emotional Intelligence and Leadership Practices
}

Kang Kooi Wei, Mohd Asri bin Mohd Noor, Mahaliza binti Mansor \& Zainudin Awang

To Link this Article: http://dx.doi.org/10.6007/IJARBSS/v11-i12/11422

DOI:10.6007/IJARBSS/v11-i12/11422

Received: 23 October 2021, Revised: 25 November 2021, Accepted: 09 December 2021

Published Online: 29 December 2021

In-Text Citation: (Wei et al., 2021)

To Cite this Article: Wei, K. K., Noor, M. A. bin M., Mansor, M. binti, \& Awang, Z. (2021). Mediating Role of Organizational Culture in The Relationship Between Emotional Intelligence and Leadership Practices. International Journal of Academic Research in Business and Social Sciences, 11(12), 2190-2205.

Copyright: (C) 2021 The Author(s)

Published by Human Resource Management Academic Research Society (www.hrmars.com)

This article is published under the Creative Commons Attribution (CC BY 4.0) license. Anyone may reproduce, distribute, translate and create derivative works of this article (for both commercial and non0-commercial purposes), subject to full attribution to the original publication and authors. The full terms of this license may be seen at: http://creativecommons.org/licences/by/4.0/legalcode

Vol. 11, No. 12, 2021, Pg. 2190- 2205

Full Terms \& Conditions of access and use can be found at http://hrmars.com/index.php/pages/detail/publication-ethics 


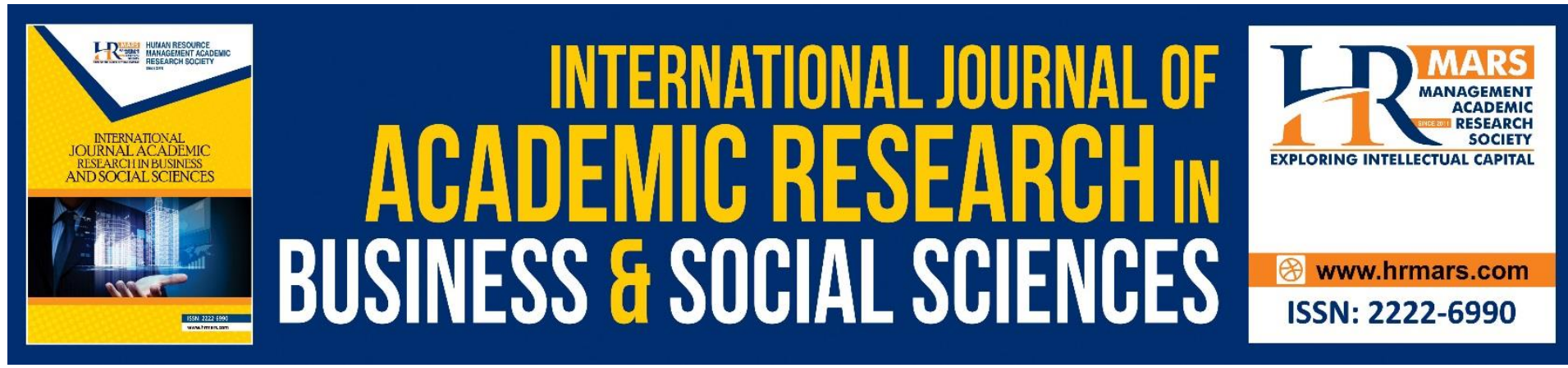

\title{
Mediating Role of Organizational Culture in The Relationship between Emotional Intelligence and Leadership Practices
}

\author{
${ }^{1}$ Kang Kooi Wei, ${ }^{2}$ Mohd Asri bin Mohd Noor, ${ }^{3}$ Mahaliza binti \\ Mansor \& ${ }^{4}$ Zainudin Awang \\ 1,2,3Universiti Pendidikan Sultan Idris, Tg. Malim, Perak, ${ }^{4}$ Universiti Sultan Zainal Abidin, \\ Kuala Terengganu, Terengganu. Malaysia
}

\begin{abstract}
This study intends to highlight the important of Organizational Culture as a bridge between Emotional Intelligence and Leadership Practices among lecturers in Matriculation College. This study applied simple random sampling from the list of lecturers. The selected respondents were given a self-administered questionnaire for data collection. The study employed the second-generation method of multivariate analysis known as Structural Equation Modeling (SEM) in IBM-SPSS-AMOS 24.0. The results were reconfirmed through bootstrapping procedure. The analysis showed that Organizational Culture fully mediates the relationship between Emotional Intelligence and Leadership Practices. The results highlighted the importance of organizational culture in generating lecturers' leadership practices. At present, the study on the mediating role of organizational culture in the relationship between emotional intelligence and leadership practices is limited especially in the Matriculation College. This study adds a remarkable contribution to the literature especially in Malaysia context.
\end{abstract}

Keywords: Organizational Culture, Emotional Intelligence, Leadership Practices, CFA and Matriculation College

\section{Introduction}

A college is a social organization that has its own values, beliefs, practices and culture. Organizational culture is values and assumptions that are widely shared and have been clearly understood in an organization (Schein, 1992). According to Sergiovanni (2003), culture involves customary value systems beliefs and practices for all members of an organizational members and bind them as a team. Teacher leaders play an important role in creating an environment that has a positive culture in schools. To create a positive culture, a teacher leader must have high emotional intelligence. School success is related to leaders' emotional intelligence such as being empathetic, being aware of one's and own emotions as well as knowing when and how possess emotional intelligence will understand the important role their emotional management plays in shaping school culture (Komin, 2000).

According to Angelle et al (2011), there are many teachers who practice teacher leadership roles do not consider themselves as leaders because they argue that teacher 
leadership refers to teachers who have specific formal positions and responsibilities such as head teachers and principals. With this it can be concluded that although there is exposure of knowledge in teacher leadership through professional development programs, but the level of mastery of teacher leadership knowledge is still limited and indirectly teacher leadership practice will also be affected. This situation will hinder the development of education towards excellence.

The study conducted by Hunani et al (2014) examined the relationship between emotional intelligence with transformational leadership and transactional leadership. The study of Hunani et al (2014) used bivariate analysis with Pearson correlation method to examine the relationship between emotional intelligence with transformational leadership with transactional leadership. In addition, Zuraidah et al (2014) conducted a study on emotional competence as a catalyst for the effectiveness of teacher leadership practices using Pearson correlation analysis. Whereas the study conducted by Ramchunder and Martins (2014) suggested more advanced data analysis methods such as multiple regression analysis or Structural Equation Modelling could be used in future studies. Moreover, Van Den Berg and Wilderom (2017) also stated that school culture constructs and leadership style constructs are closely related in the proposal for further study. Recently, studies investigating the relationship between the three variables of organizational culture, lecturers' emotional intelligence and leadership practices are still limited. Thus, a quantitative study on mediating role of organizational culture in the relationship between emotional intelligence of lecturers and leadership practices was conducted to fill this research gap.

\section{Objective}

The objective of this study is to determine the mediating role of Organizational Culture in the relationship between Emotional Intelligence and Leadership Practices among the lecturers in Matriculation College Malaysia.

\section{Literature Review \\ Organizational Culture}

Organizational culture is important in the $21^{\text {st }}$ century because organizational culture has an impact on employee performance (Naicker, 2018). Gidden (1994) emphasized that an organizational need to have a positive culture. This statement is extended by Faizal et al (2014) that a positive organizational culture can create organizational citizens who behave in a team manner. A team culture which is a positive culture plays an important role in developing leadership capacity among lecturers. Organizational leaders play an important role in an organization. Leaders for each organization need to understand the dynamic culture on the organization so that they can capitalize on the insights generated by the culture perspective and exercise more control over their organization (Igbinovia and Popoola, 2016). Therefore, organizational culture plays a role in encouraging lecturer leadership practices among matriculation college lecturers of the Ministry of Education Malaysia.

\section{Emotional Intelligence}

Goleman (2000) defines emotional intelligence as a person's ability to recognize our own feelings and the feelings of others, the ability to motivate oneself and the ability to manage the emotions of oneself and others well. According to Khaef Elahi and Duster (2003), the emotional intelligence possessed by a person allows the person to see the effects of emotional intelligence through empathy and behave in a way to improve his feelings through 
relationship management. For this study, emotional intelligence refers to a teacher's ability to communicate and socialize with others with his or her ability to manage his or her emotions well.

\section{Leadership Practices}

Ogawa and Bosset (1995) stated that leadership as an organizational quality, includes participations of teachers in instructional, professional, and organizational development. Whereby leadership must affect more than individuals' actions and influence the system in which actions occur. Organization especially school whose teachers take on leadership roles become more democratic than dictatorial (Barth, 2001).

Teacher leaders are those contribute to and influence the improved educational practice of teachers within their school (Katzermeyer and Moller, 2001). Gabriel (2005) emphasized that teacher leaders are those who create and oversee a successful team, equipping others with valuable resources to improve student achievement. According to York-Barr and Duke (2004), the roles of teacher leaders include taking part in school-wide decision making, being mentor teachers, facilitating the professional growth of other teachers, and fostering collaborative work arrangements.

The professional culture plays the important role in quality of teaching and learning. As mentioned by Hargreaves and Evans (1997), quality of teaching and learning is affected by the quality of professional relationship that outside of the classroom. The teachers who lead their peers must be respected and regarded as highly qualified professionals by the others teachers they are leading. Leadership practices among lecturers in this study defines as the lecturer who facilitate change in and out of the classroom formally or informally.

\section{The relationship between Organizational Culture and Leadership Practices}

The success of a school and the achievement of students' excellence are greatly influenced by teachers and principals who are leaders. Competent leaders can influence teachers to perform teaching tasks effectively (Shafinaz et al., 2017). A study conducted by Hamidah et al (2017) showed that there is a significant relationship between school culture and teacher leadership factors. The relationship between school culture and teacher leadership is strengthened by a study conducted by Hamidah et al. (2016) who have research findings that the relationship between school culture and leadership is strong, positive and significant $(r=0.781)$.

Turan and Bektas (2013) define school leadership with school culture as a nesting process. This statement can be identified with the findings of a study conducted by Turan and Bektas (2013) who stated that there is a positive and significant relationship between primary school teachers' perceptions of school culture with leadership practices among headmasters.

\section{The Relationship between Emotional Intelligence and Leadership Practices}

The excellence of a leader depends on the emotional intelligence of the leader. Leaders who have strong emotional intelligence can control their emotions and behavior. In addition, this leader is also able to understand his subordinates better and in turn establish a good relationship with his followers. This harmonious atmosphere can guarantee the quality of the organization because the stability of relationships between members of the organization can be enhance organizational excellence (Shafinaz et al., 2016). Thus, the emotional intelligence of a leader is related to the effective leadership style of the leader. 
The findings of the study conducted by Hudani et al (2014) show that there is a positive and significant relationship between emotional intelligence with transformational leadership and transactional leadership. The findings of this study are also supported by the study conducted by Karen Kay Wendorf-Heldt (2009) who showed that there is a strong and positive correlation between the emotional intelligence of school leaders with leadership practices in study-based school.

Moreover, a study conducted by McCleskey (2015) who examined the relationship between emotional intelligence model and leadership practices of organizational leaders and entrepreneurs has shown a positive correlation between emotional intelligence and leadership practices of organizational leaders $(r=0.23 ; p<0.001)$.

Thusly, this study aims to highlight the important of Organizational Culture as a bridge between Emotional Intelligence and Leadership Practices among lecturers in Matriculation College.

\section{Methods}

This study employed a cross-sectional design to obtain data for the field study. The target population of the study was lecturers of Matriculation College in Malaysia.

\section{Data Collection}

This study randomly selected 327 lecturers using simple random sampling. The selected respondents were given a self-administered questionnaire through their college as well as an email address. The data were analyzed using SEM procedure in IBM-SPSS-AMOS 24.0.

\section{Results and Discussion}

\section{Confirmatory Factor Analysis (CFA)}

This study has a total of three latent constructs, namely Organizational Culture (Mediator construct), Emotional Intelligence (Exogenous construct) and Leadership Practices (Endogenous construct). All constructs in the model are second order construct.

Organizational Culture measured six components namely Dominant Characteristics, Organizational Leadership, Management of Employees, Organizational Glue, Strategic Emphases and Criteria of Success. Emotional Intelligence measured four components namely Self-awareness, Self-management, Social Awareness and Relationship Management. Leadership Practices measured five components namely, Model the Way, Inspire a Shared Vision, Challenge the Process, Enable Others to Act and Encourage Teamwork.

Prior to modelling the structural model and executing Structural Equation Modeling (SEM), the study needs to validate all measurement models of latent constructs for Unidimensionality, Validity, and Reliability (Awang et al., 2018; Aimran et al., 2017, 2017a; Asnawi et al., 2019; Mahfouz et al., 2019, 2020; Rahlin et al., 2019a, 2020, 2020a; Raza and Awang, 2019; 2020, 2020a; Sarwar et al., 2020). This validation procedure is called Confirmatory Factor Analysis (CFA).

The hypotheses of interest as shown in Table 1 and Figure 1.

Table 1: The hypothesis statement of the study

\begin{tabular}{lll}
\hline Hypothesis Statement & Statistical Analysis \\
\hline $\mathbf{H}_{\mathbf{1}}$ & $\begin{array}{l}\text { Organizational Culture mediates the relationship between } \\
\text { Emotional Intelligence and Leadership Practices among } \\
\text { lecturers in Matriculation College. }\end{array}$ & Bootstrapping \\
\hline
\end{tabular}




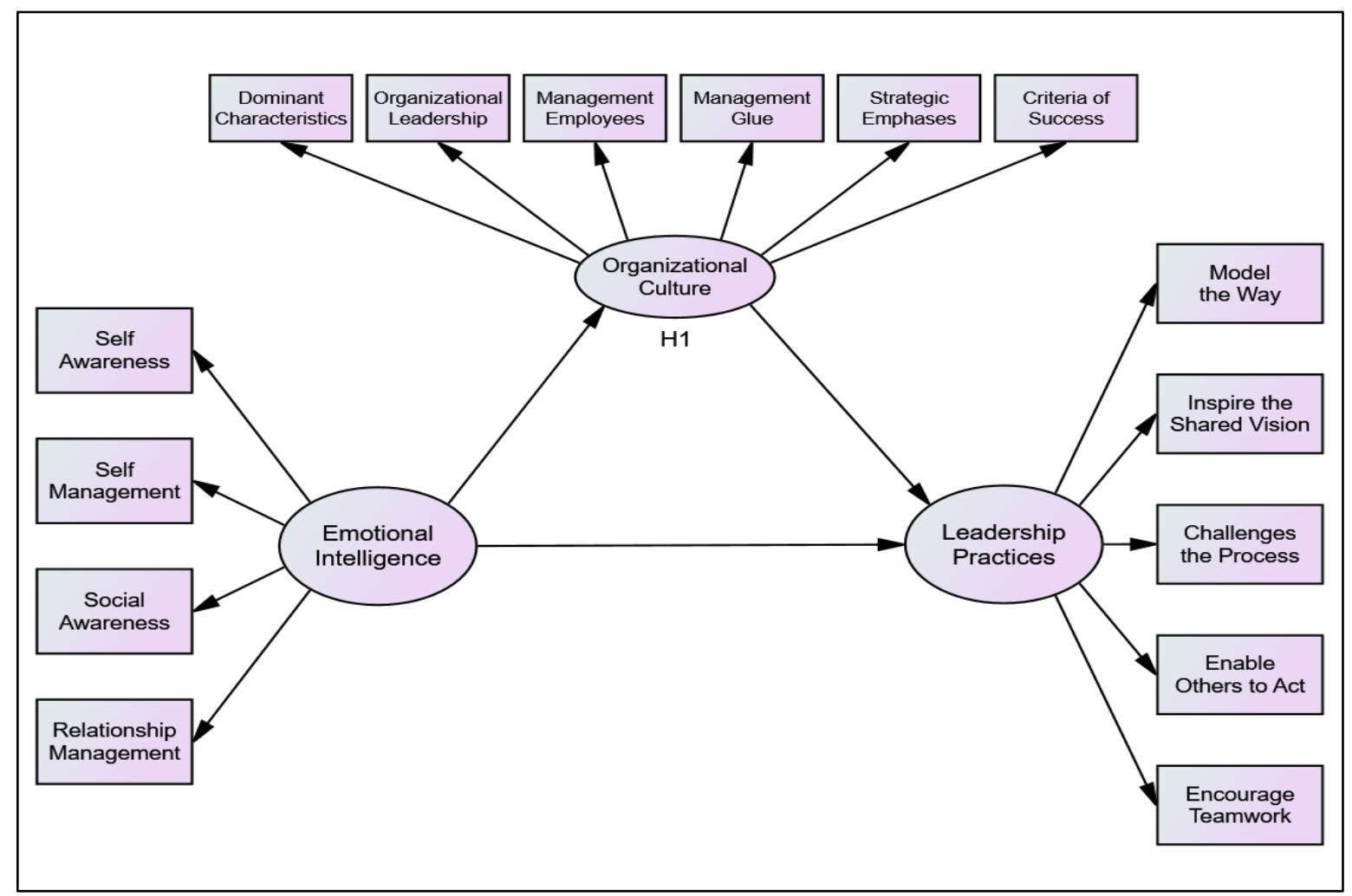

Figure 1: The framework of study showing the constructs, components and hypotheses

For the validity procedure in Confirmatory Factor Analysis, the three validity requirements are Construct Validity, which is evaluated through Fitness Indexes, the Discriminant Validity, which is evaluated through Discriminant Validity Index Summary. While the Convergent Validity is evaluated through Average Variance Extracted (AVE). The reliability is referred to the extent to which the internal consistency of the item measuring a construct. The reliability of the measurement model is evaluated through calculating the composite reliability (CR) (Awang et al., 2018; Afthanorhan et al., 2018, 2019; Mohamad et al., 2017, $2018,2019)$. The Confirmatory Factor Analysis outputs are presented in Figure 2. The measurement model in Figure 2 showed the required Fitness Indexes satisfactorily (RMSEA = $0.075, \mathrm{CFI}=0.957, \mathrm{ChiSq} / \mathrm{df}=2.841$ ), so the construct validity was achieved (Mohamad et al., 2018, 2019; Raza and Awang 2019, 2020; Bahkia et al., 2019, 2020, Sarwar et al., 2020, Afthanorhan et al., 2020, 2020a). 


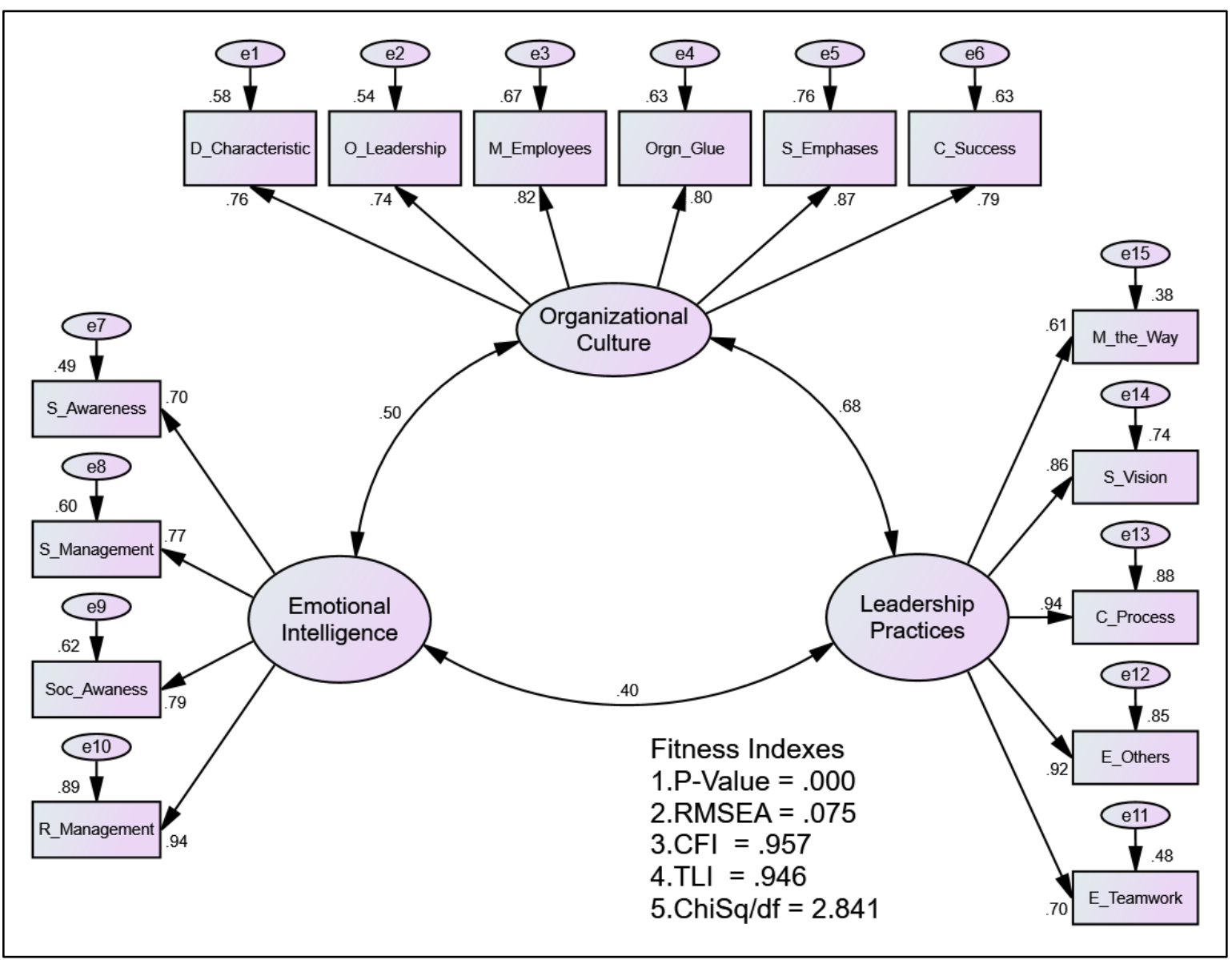

Figure 2: The Pooled-CFA Results to validate three constructs simultaneously

The value of Factor Loading in Figure 2 demonstrated all items are above 0.60, this indicated the unidimensionality of the measures (Asnawi et al., 2019; Rahlin et al., 2019b; Majid et al., 2019). The AVE values and CR values for all constructs and the discriminant validity index summary are reported in Table 2.

Table 2: Average Variance Extracted, Composite Reliability and Discriminant Validity Index Summary

\begin{tabular}{llllll}
\hline Construct & $\begin{array}{l}\text { Average } \\
\text { Variance } \\
\text { Extracted } \\
\text { (AVE) }\end{array}$ & $\begin{array}{l}\text { Composite } \\
\text { Reliability } \\
\text { (CR) }\end{array}$ & $\begin{array}{l}\text { Organizational } \\
\text { Culture }\end{array}$ & $\begin{array}{l}\text { Leadership } \\
\text { Practices }\end{array}$ & $\begin{array}{l}\text { Emotional } \\
\text { Intelligence }\end{array}$ \\
\hline $\begin{array}{l}\text { Organizational } \\
\text { Culture }\end{array}$ & 0.636 & 0.913 & $\mathbf{0 . 7 8}$ & & \\
\hline $\begin{array}{l}\text { Leadership } \\
\text { Practices }\end{array}$ & 0.666 & 0.907 & 0.68 & $\mathbf{0 . 7 2}$ & \\
\hline $\begin{array}{l}\text { Emotional } \\
\text { Intelligence }\end{array}$ & 0.648 & 0.879 & 0.50 & 0.40 & $\mathbf{0 . 8 5}$ \\
\hline
\end{tabular}

With reference to the Average Variance Extracted (AVE) and Composite Reliability (CR) values in Table 2, the study found all AVE and CR exceed their threshold values of 0.5 and 0.6 respectively (Kashif et al., 2015, 2016, Noor et al., 2015, Yusof et al., 2017; Aziz et al., 2016; Mohamad et al., 2016, 2017, 2018, 2019; Sarwar et al., 2020). Thus, the study can conclude 
that the Convergent Validity and Composite Reliability for all latent constructs in the model have been achieved.

The Discriminant Validity of the respective construct is achieved if the square root of its AVE exceeds its correlation value with other constructs in the model (Awang, 2014, 2015, Awang et al., 2015, Awang et al., 2018). In other words, the Discriminant Validity is achieved if the diagonal values (in bold) are higher than any other values in its row and its column. The tabulated values in Table 2 meet the threshold of Discriminant Validity. Thus, the study concludes that the Discriminant Validity for all constructs is achieved.

In CFA procedure, another assessment is the normality distribution of dataset. The normality distribution of the dataset is assessed using the value of skewness and kurtosis for every item. The outcome demonstrated the skewness for all components fall in the range between -1.147 and -0.333 , while the estimations of kurtosis fall in the range between -0.186 and 1.513. These two measures indicated the data does not depart from normality distribution and hence, meet the assumption for employing parametric statistics analysis (Hair et al., 2014, Awang et al., 2018, Mohamad et al., 2016, 2017, 2018, 2019, Afthanorhan et al., 2018, 2019).

\section{Structural Equation Modelling (SEM)}

The Structural Equation Modelling procedure performed utilising IBM-SPSS-AMOS 24.0 to test the hypothesis of study. Structural Equation Modelling (SEM) has accompanying points of interest; to start with, it can appraise connections among latent constructs demonstrated by indicator variables. Second, it can consider correlations among measurement errors. Third, it can measure the recursive connection between constructs. The standardized regression path coefficient is presented in Figure 3. 


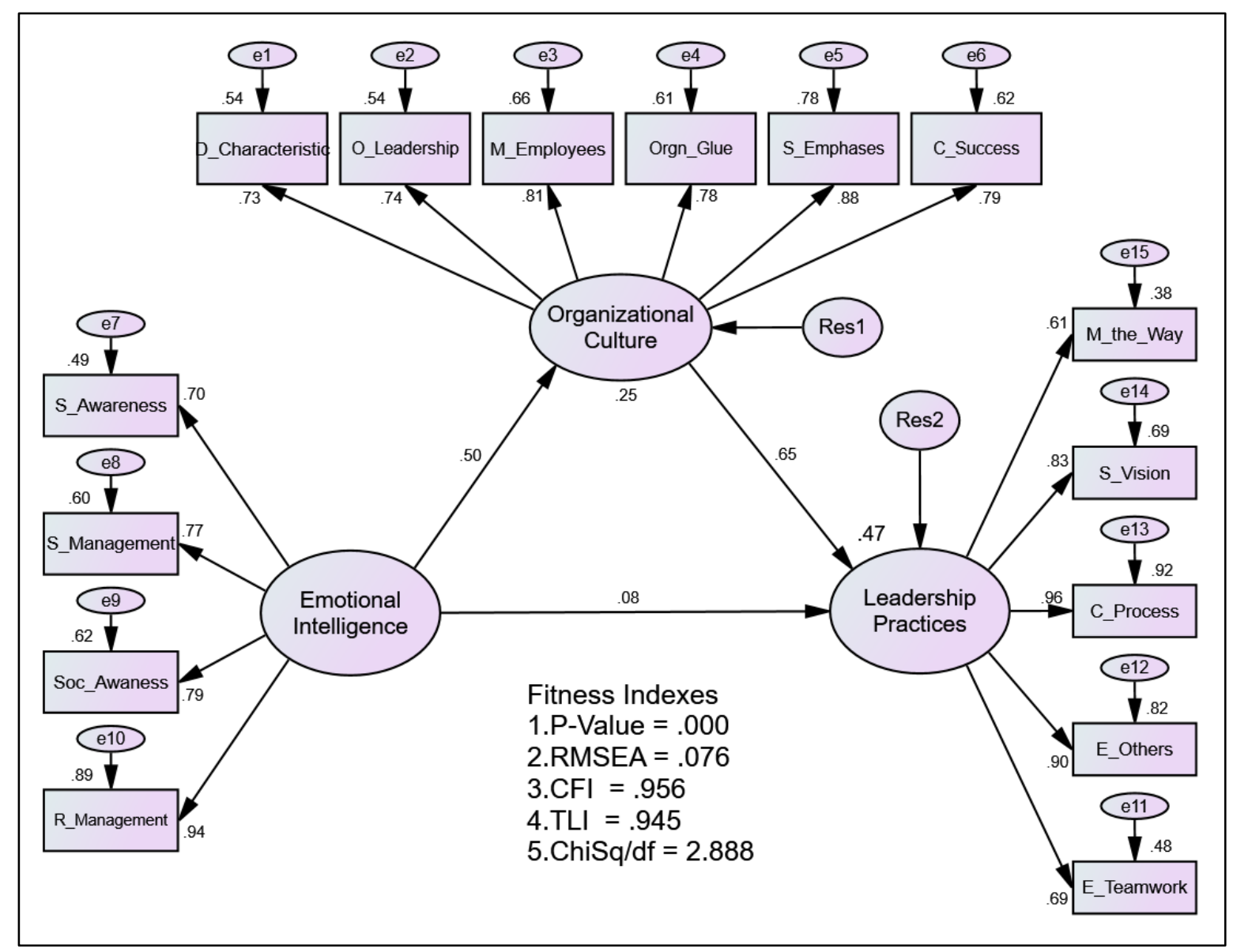

Figure 3: The Standardized Regression Path Coefficient among constructs in the model

The explanation regarding the performance of $R^{2}$ (coefficient of multiple determination) of the model (obtained from Figure 3 ) is explained in Table 3.

Table 3: The $\mathrm{R}^{2}$ and its implication in this study

\begin{tabular}{lll}
\hline $\begin{array}{l}\text { Endogenous } \\
\text { Construct }\end{array}$ & $\mathbf{R}^{\mathbf{2}}$ & \multicolumn{1}{c}{ Conclusion } \\
\hline $\begin{array}{l}\text { Leadership } \\
\text { Practices }\end{array}$ & $\mathbf{0 . 4 7}$ & $\begin{array}{l}\text { Emotional Intelligence and Organizational Culture as perceived } \\
\text { by the respondents contribute about } 47 \text { percent towards } \\
\text { Leadership Practices among lecturers in Matriculation College. }\end{array}$ \\
\hline
\end{tabular}


The Regression path coefficient among constructs in the model are shown in Figure 4.

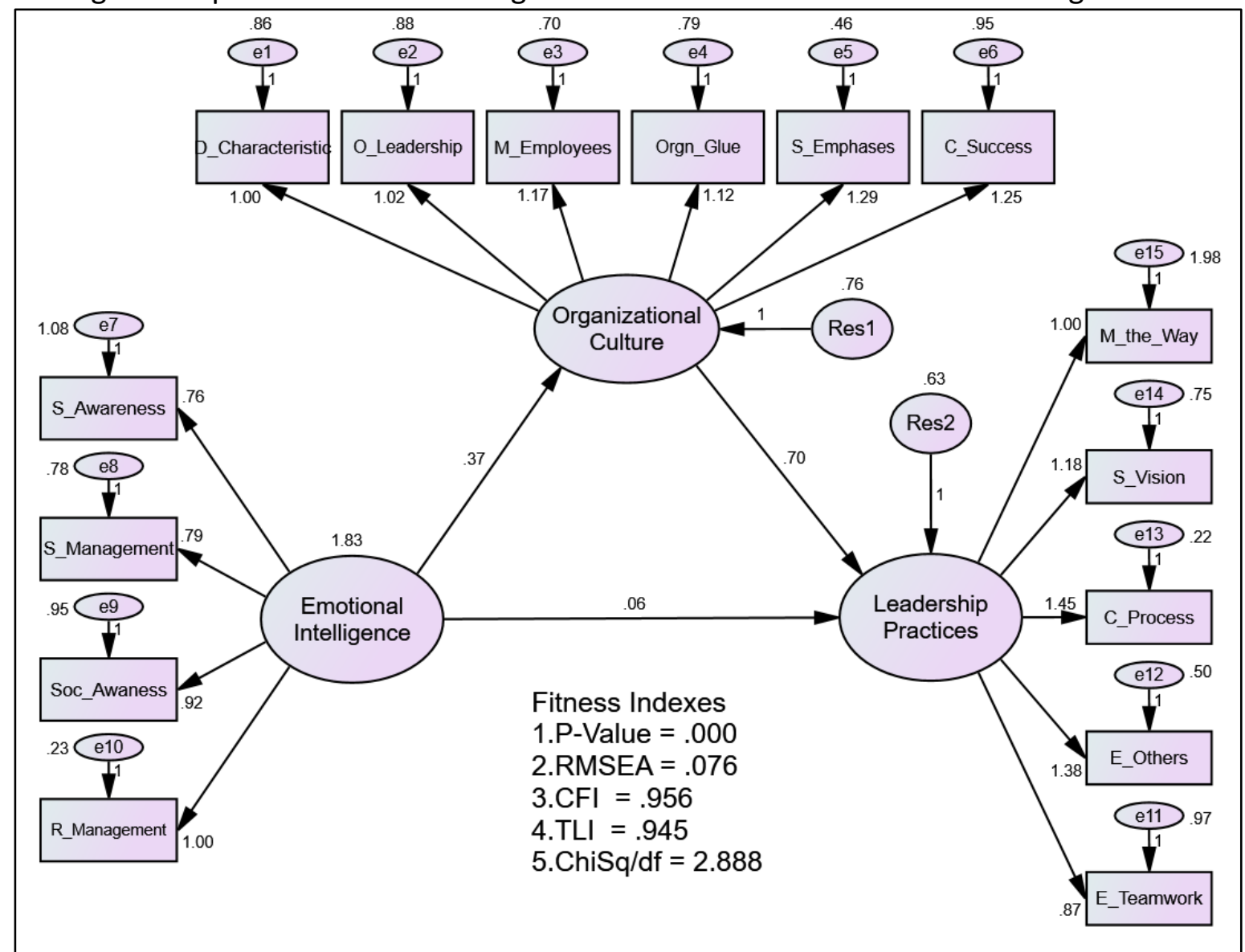

Figure 4: The Regression path coefficient among constructs in the model

The regression path coefficient between latent constructs in the model and its significance is tabulated in Table 4.

Table 4: The Regression Path Coefficient and its Significance

\begin{tabular}{|c|c|c|c|c|c|c|c|}
\hline & & & Estimate & S.E. & C.R. & $\mathbf{P}$ & Result \\
\hline $\begin{array}{c}\text { Organizational } \\
\text { Culture }\end{array}$ & $<---$ & $\begin{array}{l}\text { Emotional } \\
\text { Intelligence }\end{array}$ & .368 & .045 & 8.125 & $* * *$ & Significant \\
\hline $\begin{array}{l}\text { Leadership } \\
\text { Practices }\end{array}$ & $<---$ & $\begin{array}{c}\text { Organizational } \\
\text { Culture }\end{array}$ & .703 & .086 & 8.175 & $* * *$ & Significant \\
\hline $\begin{array}{l}\text { Leadership } \\
\text { Practices }\end{array}$ & $<---$ & $\begin{array}{l}\text { Emotional } \\
\text { Intelligence }\end{array}$ & .062 & .044 & 1.417 & .157 & $\begin{array}{c}\text { Not } \\
\text { Significant }\end{array}$ \\
\hline
\end{tabular}

The results in Table 4 are used for testing the mediator effect hypothesis. The hypothesis statement is shown in Table 5.

Table 5: Testing the Mediator Effect Hypothesis

\section{Hypothesis Statement}

$\mathbf{H}_{1} \quad$ Organizational Culture mediates the relationship between Emotional Intelligence and Leadership Practices among lecturers in Matriculation College.

The study employed the method of testing the mediation effects in the model as proposed by (Awang, 2014, 2015; Awang et al., 2015, 2018; Kashif et al., 2015, 2016). The coefficient 
values shown in Figure 5 is obtained from the standardized regression path coefficient as presented in Figure 3.

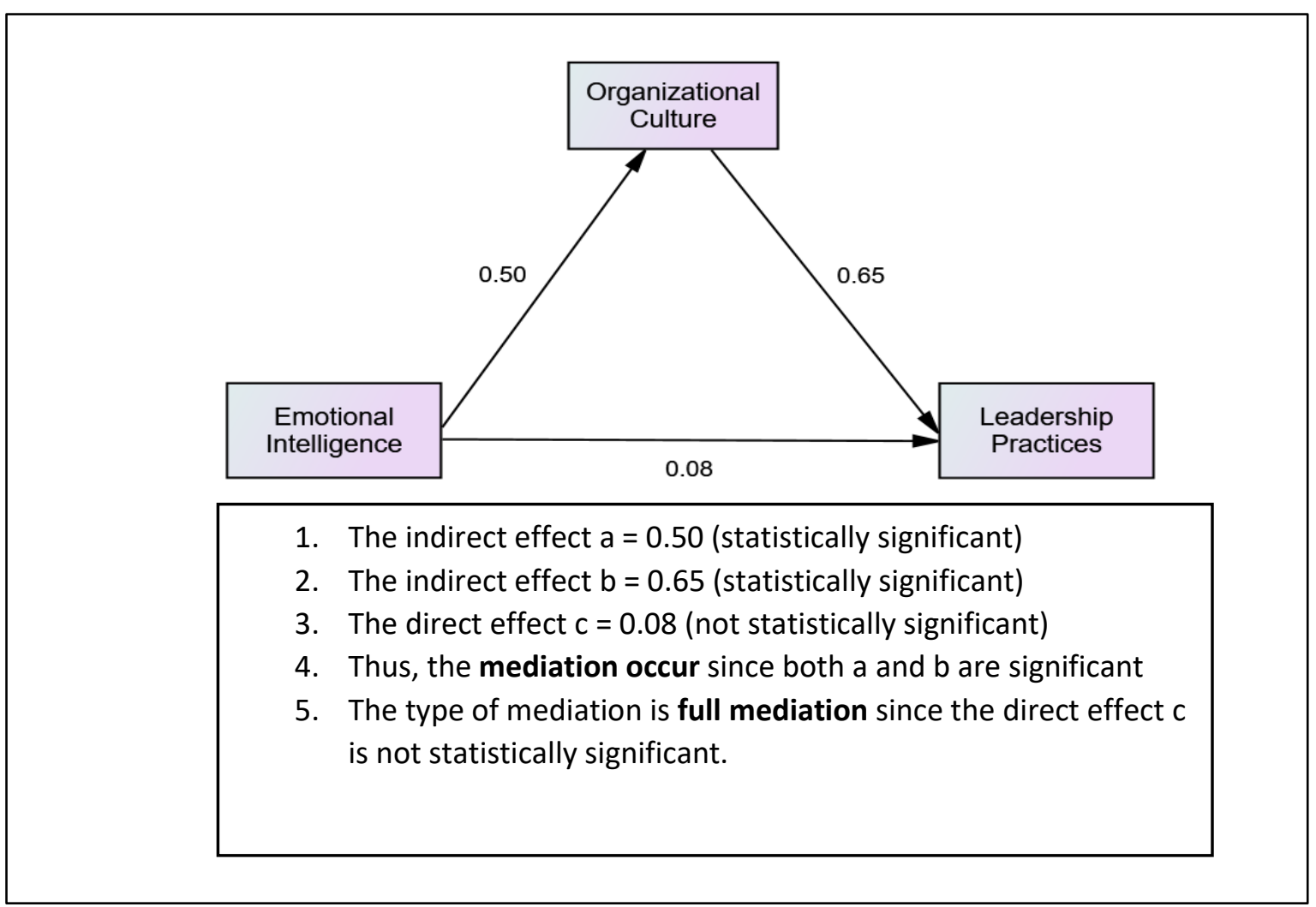

Figure 5: The Procedure for Testing Mediation Effect in the Model

\section{Confirming the Results of Mediation Test using Bootstrapping}

Once the test of hypothesis for mediation is completed, and the mediation effect occurs either as a partial mediation or full mediation, the researcher needs to confirm the test results through the resampling procedure called Bootstrapping (Awang, 2015; 2018; Kashif et al., 2015; 2016; Yusuf et al., 2017; Mohamad et al., 2018). The researcher could choose the number of bootstrap samples between 500 to 5000, the bootstrap confidence interval between $90 \%$ to $99 \%$, and bias-corrected confidence interval also between $90 \%$ to $99 \%$. From the bootstrap results, the researcher could determine the significance of mediation together with the type of mediation that occurred. The study employed the Maximum Likelihood Estimator (MLE) bootstrapping algorithm using 1000 bootstrap samples, 95\% bootstrap confidence interval and also $95 \%$ bias-corrected confidence interval. The bootstrapping results for testing mediator is presented in Table5.

Table 5: The Bootstrapping Result for Testing Organizational Culture as a Mediator

\begin{tabular}{lcc}
\hline & Indirect Effect (ab) & Direct (c) \\
\hline Bootstrapping Value & $\mathbf{0 . 3 2 1}$ & $\mathbf{0 . 0 7 7}$ \\
\hline Probability Value & $\mathbf{0 . 0 0 2}$ & $\mathbf{0 . 2 5 8}$ \\
\hline $\begin{array}{l}\text { Results on } \\
\text { Mediation }\end{array}$ & Significant & Not Significant \\
\hline & & \\
\hline & Mediation exists since indirect effects is significant. Type of \\
& mediation is full mediation since the direct effect is not significant. \\
\hline
\end{tabular}


Thus, the bootstrapping results for mediation test as presented in Table 5 has confirmed the results obtained in the mediation test conducted in Figure 5.

\section{Contribution of this Research}

Findings showed that there is insignificant relationship between Emotional Intelligence and Leadership Practices. The result indicated that Emotional Intelligence did not have a direct positive impact on Leadership Practices. The findings of the study hence confirmed that Organizational Culture plays an important role as a mediator between Emotional Intelligence and Leadership Practices among lecturers of Matriculation College in Malaysia. The great organizational culture will increase the level of lecturers' emotional intelligence and hence motivate the leadership practices among the lecturers. This research contributes remarkable theory to Matriculation College in the Malaysia context. Moreover, the results of the research can be used as a benchmark by Matriculation Division in implementing professional development programs to enhance the leadership practices among the Matriculation lecturers.

\section{Limitation}

This research mainly focused on the Matriculation lecturers in Malaysia. Therefore, this research might not be generalizable for other fields.

\section{Correspondent Author}

Kang Kooi Wei

Email: kangkooiwei@gmail.com

\section{References}

Afthanorhan, A., Awang, Z., Salleh, F., Ghazali, P., and Rashid, N. (2018), The effect of product quality, medical price and staff skills on patient loyalty via cultural impact in medical tourism. Management Science Letters, 8(12), 1421-1424.

Afthanorhan, A., Awang, Z., Rashid, N., Foziah, H., \& Ghazali, P. (2019). Assessing the effects of service quality on customer satisfaction. Management Science Letters, 9(1), 13-24.

Afthanorhan, A., Mamun, A. A., Zainol, N. R., Foziah, H., \& Awang, Z. (2020). Framing the Retirement Planning Behavior Model towards Sustainable Wellbeing among Youth: The Moderating Effect of Public Profiles. Sustainability, 12(21), 8879.

Afthanorhan, A., Awang, Z., \& Aimran, N. (2020a). An extensive comparison of CB-SEM and PLS-SEM for reliability and validity. International Journal of Data and Network Science, 4(4), 357-364.

Aimran, A. N., Ahmad, S., Afthanorhan, A., \& Awang, Z. (2017). The development of the comparative bias index. Paper presented at the AIP Conference Proceedings, 1870. https://doi.org/10.1063/1.4995935

Angelle, P. S., Nixon, T. J., Norton, E. M., \& Niles, C. A. (2011). Increasing organizational effectiveness: An examination of teacher leadership, collective efficacy, and trust in schools. Paper presented at the annual meeting of the University Council for Educational Administration, Pittsburgh.

Asnawi, A., Awang, Z., Afthanorhan, A., Mohamad, M., \& Karim, F. (2019). The influence of hospital image and service quality on patients' satisfaction and loyalty. Management Science Letters, 9(6), 911-920. https://doi.org/10.5267/j.msl.2019.2.011 
Awang, Z. (2014). A handbook on SEM for academicians and practitioners: the step-by-step practical guides for the beginners. Bandar Baru Bangi, MPWS Rich Resources.

Awang, Z. (2015). SEM Made Simple: A Gentle Approach to Learning Structural Equation Modelling. Bandar Baru Bangi, MPWS Rich Resources.

Awang, Z., Lim, S. H., \& Zainudin, N. F. S. (2018). Pendekatan Mudah SEM-Structural Equation Modelling. Bandar Baru Bangi, MPWS Rich Resources.

Awang, Z., Afthanorhan, A., Mohamad, M., \& Asri, M. A. M. (2015). An evaluation of measurement model for medical tourism research: the confirmatory factor analysis approach. International Journal of Tourism Policy, 6(1), 29-45.

Aziz, MI., Afthanorhan, A., \& Awang, Z. (2016). Talent development model for a career in Islamic Banking Institutions: A SEM approach. Cogent Business and Management, 3(1).

Bahkia, A. S., Awang, Z., Afthanorhan, A., Ghazali, P. L., Foziah, H. (2019). Exploratory Factor Analysis on occupational stress in context of Malaysian sewerage operations. AIP Conference Proceedings. https://doi.org/10.1063/1.5121111

Bahkia, A. S., Awang, Z., Rahlin, N. A., Zulkifli, A. R. (2020). The Importance of Supportive Leadership in the Sewerage Operation Industry: A case of Indahwater Konsortium Private IWK). Humanities \& Social Science Reviews, 8(3), 2020, 149-162. https://doi.org/10.18510/hssr.2020.8317

Barth, R. S. (2001). Teacher leader. Phi Delta Kappan, 82(6).

Gabriel, J. G. (2005). How to thrive as a teacher leader. Alexandria, VA: ASCD.

Giddens, A. (1994). Beyond left and right: The future of radical politics. Oxford: Polity Press.

Goleman, D. (2000). An El-based theory of performance. In C. Cherniss \& D. Goleman (Eds.), The emotionally intelligent workplace: How to Select for, Measure, and Improve Emotional Intelligence in Individuals, Groups, and Organizations. San Francisco: Jossey- Bass.

Hair, J. F., Black, W. C., Babin, B. J., \& Anderson, R. E. (2014). Multivariate Data Analysis, (7 Edition). United States: Pearson Education Limited.

Hamidah, Y., Lechumy, V., Norasibah, J. A., Mahaliza, M., \& Asri, M. N. (2017). The factors affecting teacher leadership in Malaysian primary schools. International Journal of Academic Research in Business and Social Sciences, 7(6), 620-631. https://doi.org/10.6007/IJARBSS/v7-i6/3025

Hamidah, Y., Nursalam, M. A., \& Asri, M. (2016). School culture and its relationship with teacher leadership. International Journal of Academic Research in Business and Social Sciences, 6(11), 272-286.

Hargreaves, A., \& Evans, R. (1997). Beyond educational reform: Bringing teachers back in. Buckingham England: Open University Press.

Igbinovia, M. O., \& Popoola, S. O. (2016). Organizational culture and emotional intelligence as predictors of job performance among library personnel in academic libraries in Edo State, Nigeria. Journal of Information Science Theory and Practice, 4(2), $34-52$.

Kashif, M., Awang, Z., Walsh, J., \& Altaf, U. (2015). I'm loving it but hating US: understanding consumer emotions and perceived service quality of US fast food brands. British Food Journal, 117(9), 2344-2360.

Kashif, M., Samsi, S. Z. M., Awang, Z., \& Mohamad, M. (2016). EXQ: measurement of healthcare experience quality in Malaysian settings: A contextualist perspective. International Journal of Pharmaceutical and Healthcare Marketing, 10(1), 27-47. 
Katzenmeyer, M., \& Moller, G. (2001). Awakening the sleeping giant: Helping teachers develop as leaders (2nd ed.). Thousand Oaks, CA: Corwin Press.

Komin, S. (2000). The Thai concept of effective leadership: innovations in international and cross-cultural management. California: Sage Publications Inc.

Khaef, E. A., \& Dustar, M. (2003). Emotional Intelligent dimensions. Management and Development Journal, 18, 52-62.

Mahfouz, S. A., Awang, Z., \& Muda, H. (2019). The Impact of Transformational Leadership on Employee Commitment in the Construction Industry. International Journal of Innovation, Creativity and Change, 7(10).

Mahfouz, S. A., Awang, Z., Muda, H., \& Bahkia, A.S. (2020). Mediating Role of Employee Commitment in the Relationship between Transformational Leadership Style and Employee Performance. Humanities \& Social Sciences Reviews, 8(2), 624-637. https://doi.org/10.18510/hssr.2020.8270

Majid, N. A., Zainol, F. A., Daud, W. N. W., \& Afthanorhan, A. (2019). Cooperative Entrepreneurship in Malaysian Secondary Schools: A Review of Current Practices. The Journal of Social Sciences Research, 5(3), 812-818. https://doi.org/10.32861/jssr.53.812.818

McCleskey, J. A. (2015). An examination of the relationship between ability model emotional intelligence and leadership practices of organizational leaders and entrepreneurs. Capella University.

Mohamad, M., Mohammad, M., Ali, N. A. M., \& Awang, Z. (2016). Measuring Positive Youth Development: The Confirmatory Factor Analysis (CFA). IJABER, 14(13), 9441-9451.

Mohamad, M., Awang, Z., \& Ali, N. A. M. (2017). Validating the Maqasid Shariah Prison Quality of Life (MSPQoL) among drug-abuse inmates using confirmatory factor analysis. International Journal of Applied Business and Economic Research, 15(24), 91-103.

Mohamad, M., Ali, N. A. M., \& Awang, Z. (2018). The impact of life satisfaction on substance abuse: delinquency as a mediator. International Journal of Adolescence and Youth, 23(1), 25-35.

Mohamad, M., Afthanorhan, A., Awang, Z., \& Mohammad, M. (2019). Comparison Between CB-SEM and PLS-SEM: Testing and Confirming the MaqasidSyariah Quality of Life Measurement Model. The Journal of Social Sciences Research, 5(3), 608-614. https://doi.org/10.32861/jssr.53.608.614

Naicker, N. (2008). Organizational culture and employee commitment: A case study (unpublished dissertation). Durban University of Technology.

Noor, N. M., Aziz, A. A., Mostapa, M. R., \& Awang, Z. (2015). Validation of the Malay version of the Inventory of Functional Status after Childbirth questionnaire. BioMed research international.

Nunnally, J. C. (1978). An overview of psychological measurement, In Clinical diagnosis of mental disorders. Springer, Boston, MA.

Norman, A. S. (2010). Importance of financial education in making informed decision on spending. Journal of economics and International Finance, 2(10), 199-207. https://doi.org/10.1007/978-1-4684-2490-4_4

Ogawa, R., \& Bosset, S. T. (1995). Leadership as an organizational quality. Educational administration quarterly, 31(2), 224-243.

Rahlin, N. A., Awang, Z., Afthanorhan, A., \& Aimran, N. (2019a). Antecedents and Consequences of Employee Safety Climate in Small Manufacturing Enterprises: 
Translation, Validation and Application of Generic Safety Climate Questionnaire. International Journal of Innovation, Creativity and Change, $7(10)$.

Rahlin, N. A., Awang, Z., Afthanorhan, A., \& Aimran, N. (2019b). The Art of Covariance Based Confirmatory Factor Analysis: Evidence from SME'S. International Journal of Innovation, Creativity and Change, 5(2).

Rahlin, N. A., Awang, Z., Zulkifli, A. R., \& Bahkia, A. S. (2020). The Impact of Employee Safety Climate on Safety Behavior in Small and Medium Enterprises: An Empirical Study. Humanities and Social Science Reviews, 8(3), 163-177. https://doi.org/10.18510/hssr.2020.8318

Rahlin, N. A., Awang, Z., Zulkifli, A. R., \& Bahkia, A. S. (2020a). The Direct Effect of Climate Emergence and Safety Climate on Intention to Safety Behavior. Humanities and Social Science Review, 8(3), 178-189. https://doi.org/10.18510/hssr.2020.8319

Ramchunder, Y., \& Martins, N. (2014). The role of self-efficacy, emotional intelligence and leadership style as attributes of leadership effectiveness. SA Journal of Industrial Psychology/SA Tydskrif vir Bedryfsielkunde, 40(1), 11. http://dx.doi.org/10.4102/sajip.v40i1.1100

Raza, I., Chaudhry, A. R., \& Awang, Z. (2019). Knowledge Sharing Behaviour of Multiracial Staff Engaged in Industrial Firms of Islamabad, Pakistan. International Journal of Academic Research in Business and Social Sciences, 9(11).

Raza, I., \& Awang, Z. (2020). Knowledge sharing in multicultural organizations: evidence from Pakistan. Higher Education, Skills and Work-Based Learning https://www.emerald.com/insight/2042-3896.htm

Raza, I., \& Awang, Z. (2020a). Knowledge-sharing practices in higher educational institutes of Islamabad, Pakistan: an empirical study based on theory of planned behavior. Journal of Applied Research in Higher Education. https://doi.org/10.1108/JARHE-03-20200068

Sarwar, M. A., Awang, Z., Habib, M. D., Nasir, J., \& Hussain, M. (2020). Why did I buy this? Purchase regret and repeat purchase intentions: A model and empirical application. Journal of Public Affairs.

Sekaran, U. (2009). Research methods for business (4 ${ }^{\text {th }}$ Edition). Hoboken: NJ: John Wiley \& Sons.

Sekaran, U., \& Bougie, R. (2010). Research Methods for Business: A Skill Building Approach. Wiley.

Schein, E. H. (1992). Organizational culture and leadership. San Francisco: Jossey-Bass.

Shafinaz, A. M., Chua, Y. P., Hussein, A., Leong, M. W., \& Shahrin, A. (2016). Kecerdasan emosi pengetua dan hubungannya dengan efikasi kendiri guru sekolah menengah. Jurnal Kepimpinan Pendidikan, 3(3), 54-75.

Taylor, M. (2003). Ideas That Bring People Together: A Review of Thomas J. Sergiovanni's "Leadership: What's in It for Schools?". Journal of Thought, 38(4), 133-135. http://www.jstor.org/stable/42589768

Turan, S., \& Bektas, F. (2013). The relationship between school culture and leadership practices. Eurasian Journal of Educational Research, 52, 155-168.

Van Den Berg, P. T., \& Wilderom, C. Pm. (2004). Defining, measuring and comparing organizational cultures. International Association for Applied Psychology.

Wendorf-heldt, K. K. (2009). Emotional intelligence: The link to school leadership practices that increase student achievement. Cardinal Stritch University. 
Ali, W. S. N., \& Noori, S. (2018). The pillars of Blue Ocean leadership and their impact on team empowerment strategies.

York-Barr, J., \& Duke, K. (2004). What Do We Know about Teacher Leadership? Findings from Two Decades of Scholarship. Review of Educational Research, 74(3), 255-316. http://www.jstor.org/stable/3516026

Yusof, Y., Awang, Z., Jusoff, K., \& Ibrahim, Y. (2017). The influence of green practices by nongreen hotels on customer satisfaction and loyalty in hotel and tourism industry. International Journal of Green Economics, 11(1), 1-14.

Zuraidah, J. M., Yusoff, Y. D., \& Siti, N. I. (2014). Kompetensi emosi pemangkin keberkesanan amalan kepimpinan guru. Jurnal Kepimpinan Pendidik. 